\title{
Genetic parameters, correlation and repeatability of agronomic characters of yellow passion fruit genotypes in three harvest cycles
}

\author{
Onildo Nunes de Jesus ${ }^{1, \star}$ (D), Lucas Kennedy Silva Lima² (iD, Plácido Ulisses Souza³ (iD, Eduardo Augusto \\ Girardi $^{1}$ (D) \\ 1. Empresa Brasileira de Pesquisa Agropecuária - Embrapa Mandioca e Fruticultura - Pesquisa e Desenvolvimento - Cruz das Almas (BA), \\ Brazil. \\ 2. Empresa Brasileira de Pesquisa Agropecuária - Embrapa Mandioca e Fruticultura - Cruz das Almas (BA), Brazil. \\ 3. Universidade Federal do Recôncavo da Bahia - Centro de Ciências Agrárias, Ambientais e Biológicas - Pós-Graduação em Ciências Agrárias \\ - Cruz das Almas (BA), Brazil.
}

Received: Jun. 26, 2020 | Accepted: Jan. 11, 2021

Section Editor: Gabriel Constantino Blain

*Corresponding author: onildo.nunes@embrapa.br

How to cite: Jesus, O. N., Lima, L. K. S., Souza, P. U. and Girardi, E. A. (2021). Genetic parameters, correlation and repeatability of agronomic characters of yellow passion fruit genotypes in three harvest cycles. Bragantia, 80, e1621. https://doi.org/10.1590/1678-4499.20200294

\begin{abstract}
The genetic improvement of sour passion fruit has the main objective of obtaining genotypes with high fruit yield and quality. The determination of the ideal early selection is extremely relevant to reduce costs and time in the selection of promising genotypes for use in genetic improvement programs. In this context, this work aimed to determine the ideal selection phase through estimates of genetic parameters, phenotypic, genotypic correlations and analysis of repeatability. A total of 14 yellow passion fruit hybrids in Lençóis (Bahia State, Brazil) were evaluated in a randomized block design with five replications and nine agronomic traits from three harvests with five fruits evaluated per repetition. Genetic parameters, repeatability coefficient and phenotypic and genotypic correlations were estimated for each evaluation cycle. For most parameters, the traits changed according to the evaluation cycle. Most of the genetic parameters showed favorable genetic conditions for the selection in the first harvest. The correlations between the traits fruit weight, peel and seedless pulp weight, fruit length and diameter were more stable in the different harvests. Through the repeatability analysis based on the principal components of covariance and correlation, it was possible to estimate a sample of 13 fruits per hybrid for prediction with accuracy of $90 \%$ for the physical traits of sour passion fruit.
\end{abstract}

Key words: Passiflora edulis Sims, breeding, heritability, repeatability analysis, genotypic correlation, early selection.

\section{INTRODUCTION}

The genetic breeding programs of sour passion fruit (Passiflora edulis Sims) aims to obtain genotypes with high productive potential and fruit quality, such as high juice yield and content of soluble solids and low acidity. In addition, resistance is necessary to the main pathogens that shorten the lifespan of orchards in different regions of Brazil (Lima et al. 2018; Pereira et al. 2019; Santos et al. 2019).

For the selection of genetically superior genotypes, several morpho-agronomic traits are considered. Correlation analysis between traits contributes to the selection of promising genotypes, since the technique allows selecting traits that are difficult to measure but that have complex inheritance with another trait that is easy to measure (Oliveira et al. 2011; Alves et al. 2012; Malek et al. 2014). This strategy allows faster progress in relation to the use of direct selection (Carvalho et al. 2004; Moraes et al. 2005). The association of correlation analysis with determination of other genetic parameters of genotypic, phenotypic and environmental variation and heritability is fundamental to obtain information on the population (Moraes et al. 2005; Bergo et al. 2019) and to understand the action of genes involved in trait control (Silva et al. 2012). 
The successive evaluation of a genotype is desirable, because the individual performance is expected to remain constant during the investigated period (Santos et al. 2010). However, the successive assessment of many characteristics over an extended period is time-consuming and expensive (Santos et al. 2010). Thus, repeatability analysis is of great importance, since it allows to determine the correlation of these measures of the genotype under evaluation and allows to predict the minimum number of measures to provide acceptable accuracy of information.

The estimate of the repeatability coefficients expresses the proportion of the total variance that is explained by the variations of the genotype. The correlation between the measures obtained from the same plant in time or space also indicates the maximum value that heritability in the broad sense can reach (Cruz et al. 2004; Ferreira et al. 2005). High values for the estimate of character repeatability indicate that it is possible to predict the real value with a relatively small number of measurements, so that the gain in accuracy with a greater number of measurements is irrelevant (Bruna et al. 2012). However, when the repeatability is low, a large number of repetitions will be necessary to reach a satisfactory determination value that will vary with the nature of each of the traits to be evaluated (Cruz et al. 2004; Neves et al. 2010).

Studying yellow passion fruit, Cavalcante et al. $(2017,2018)$ used two production cycle periods, but only three traits related to fruit production and weight. However, there are no studies evaluating more characteristics with an estimate of genetic components, correlation and repeatability in association with different cycle of harvests. This approach helps to understand the changes that can occur in these parameters as a function of the evaluation epoch, with implications for breeding genetics. In addition, the selection of the cycle where the environmental factors are less pronounced regarding phenotype and which has the genetic component as the predominant factor in the evaluated phenotype allows estimates of important genetic parameters with better precision, consequently resulting in superior selective response for the genotypes under the evaluated conditions. Furthermore, the genotypic observations according to the initial harvests can accelerate the selection process and consequently reduce the cost of breeding programs. This acceleration is particularly interesting for the selection of yellow passion fruit, since the lifespan of the crop is declining due to the high incidence and severity of diseases (Oliveira et al. 2013; Lima et al. 2018; Pereira et al. 2019). Under ideal conditions, the culture is maintained commercially for up to four years, but this falls to one year in the presence of diseases caused by viruses and fungi, such as fusarium wilt (Oliveira et al. 2013; Pereira et al. 2019). On the other hand, passion fruit propagated by seeds can start fruiting five to eight months after planting, which can allow more than one evaluation in the productive cycle of the crop. Thus, a study of the components of variance, correlation and repeatability of the characters of production and fruit traits can support the selection and recombination, aiming to accelerate the process of genetic improvement of the species. The objective of this study was to determine the most suitable harvest cycle for selection, based on genetic components of variance, phenotypic and genotypic correlation and repeatability of the agronomic characters of sour passion fruit hybrids evaluated in three harvest periods.

\section{MATERIALS AND METHODS}

\section{Experiment location}

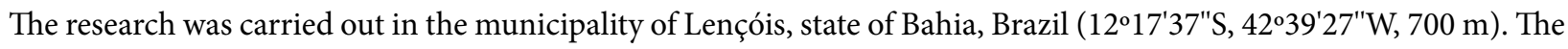
local climate is classified as $\mathrm{Cwb}$ mesothermal by the Köppen classification. The climate conditions of the evaluation period were average maximum temperature of $30^{\circ} \mathrm{C}$, average minimum of $18{ }^{\circ} \mathrm{C}$, relative humidity of $68 \%$ and precipitation of 0.31 to $7.37 \mathrm{~mm}$ per day. The soil is classified as yellow red dystrophic latosol (oxisol) with clayey texture (Embrapa 1999) and has the following chemical attributes in the 0-20 cm layer: $\mathrm{pH}\left(\mathrm{H}_{2} \mathrm{O}\right) 6.50$; $\mathrm{P} 18\left(\mathrm{mg}^{-\mathrm{dm}^{-3}}\right)$; $\mathrm{K} \mathrm{0.15}$; Ca 4.30; $\mathrm{Mg} 2.30$; $\mathrm{Al}$ 0.0; $\mathrm{H}+\mathrm{Al}$ 3.08; CEC $9.91\left(\mathrm{cmol}_{\mathrm{c}} \mathrm{dm}^{-3}\right) ; \mathrm{V}(\%) 69 ;$ O.M. $47.6 \mathrm{~g} \cdot \mathrm{kg}^{-1}$ of soil.

\section{Plant material and experimental design}

Were evaluated 14 intraspecific hybrids of sour passion fruit (P. edulis Sims), 12 intraspecific hybrids of the HFOP-01 series to 12 , from crosses between parents selected due to the higher productivity and physical and chemical attributes 
of fruits of interest (Neves et al. 2013), and two commercial hybrids, BRS Sol do Cerrado (BRS-SC1) and BRS Gigante Amarelo (BRS-GA1). The experimental design used was randomized blocks, with 14 treatments, five replications and 12 plants per plot.

Ninety days after sowing, the seedlings produced under an anti-aphid screen were planted in the field with a simple wire at height of $2 \mathrm{~m}$ and planting spacing of $4.0 \times 2.5 \mathrm{~m}$. The plants were irrigated in an organic production system, according to the guidelines of the Embrapa production system (Embrapa 2018). Due to the presence of pollinating insects, no artificial pollination was carried out in the planting area.

\section{Variables collected}

The traits analyzed were total accumulated yield $\left(\mathrm{t}^{-h} \mathrm{a}^{-1}\right)$, number of fruits per plant (NF), fruit weight (FW), length (FL) and diameter (FD), peel thickness (PT), peel weight (PW), seedless pulp weight (PuW) and juice yield (JY), given by the $\mathrm{PuW} / \mathrm{FW}$ ratio in percentage. The evaluation was performed using an illustrated manual of the descriptors for Passiflora (https://bit.ly/3oR0SYp; Jesus et al. 2017). For each harvest, five fruits were analyzed per plot. To estimate productivity, the number of fruits in the plot was counted. All traits were evaluated at three harvest times: 184 (harvest 1 or H1), 334 (harvest 2 or H2) and 441 (harvest 3 or H3) days after planting.

\section{Genetic parameters}

The estimated genetic parameters were determined based on expected mean square of the analysis of variance (ANOVA), considering treatment as a random effect (Cruz et al. 2004). The estimated parameters were coefficient of genetic variation $\left(\mathrm{CV}_{\mathrm{g}}\right)$, residual (experimental) coefficient of variation $\left(\mathrm{CV}_{\mathrm{e}}\right), \mathrm{CV}_{\mathrm{g}} / \mathrm{CV}_{\mathrm{e}}$ ratio, phenotypic variance $\left(\sigma_{\mathrm{p}}^{2}\right)$, genetic variance $\left(\sigma_{\mathrm{g}}^{2}\right)$, environmental variance or residual variance $\left(\sigma_{\mathrm{e}}^{2}\right)$ and heritability $\left(\mathrm{h}^{2}\right)$.

\section{Correlation}

For correlation analysis, the phenotypic (rf) and genotypic ( $\mathrm{rg}$ ) correlations were estimated as described by Cruz et al. (2004). The magnitudes of the correlation coefficients were established according to the classification by Carvalho et al. (2004): $\mathrm{r}=0$ (null); $0<|\mathrm{r}| \leq 0.30$ (weak); $0.30<|\mathrm{r}| \leq 0.60$ (medium); $0.60<|\mathrm{r}| \leq 0.90$ (strong); $0.90<|\mathrm{r}|<1$ (very strong) and $|\mathrm{r}|=1$ (perfect). All analyses were performed using the Genes program (Cruz 2013).

\section{Repeatability analysis}

To determine the repeatability coefficient, four methods were used: 1) ANOVA for each trait described and estimation of the components of variance associated with the genetic and residual effects; 2) principal component analysis based on the correlation matrix (PCCOR);3) principal component analysis based on the covariance matrix (PCCOV) between each pair of measurements (Abeywardena 1972) and 4) structural analysis based on the correlation matrix (SACOR) between the accessions in each evaluation pair (Mansour et al. 1981). For repeatability analysis, the character measurements of the fruits within each plot were considered, using the average obtained in each of the five repetitions in order to check if there was consistency of the data obtained for the five fruits of each harvest.

The repeatability coefficient $(R)$ was estimated through the results of ANOVA (Cruz et al. 2004). For each characteristic, the minimum number $\left(n_{0}\right)$ of measurements necessary to predict the real value of the genotypes was determined, based on predetermined coefficients of determination $\left(\mathrm{R}^{2}\right)$ of $0.85,0.90$ and 0.95 (Cruz et al. 2004). For each characteristic, the determination coefficient $\left(R^{2}\right)$ was calculated based on the average of $\eta$ measurements and the estimation of the repeatability coefficients obtained according to one of the methods used. The repeatability was classified as follows: high repeatability $(\mathrm{r} \geq 0.60)$; medium repeatability $(0.30<\mathrm{r}<0.60)$ and low repeatability $(\mathrm{r} \leq 0.30)$ (Resende 2002). 


\section{RESULTS}

\section{Genetic parameters}

The evaluations carried out over the three production harvests ( $\mathrm{H} 1, \mathrm{H} 2$ and $\mathrm{H} 3)$ of the 14 hybrids of sour passion fruit demonstrated variability for most traits within and between the evaluation harvest (Table 1 ). The $\mathrm{CV}_{\mathrm{g}}$ ranged from 3.96 to $21.02 \%$ for the characteristics of FD and production (PR), respectively. Approximately $66.67 \%$ of $\mathrm{CV}_{\mathrm{g}}$ values were above $10 \%$, with considerable variability even in the case of previously selected individuals, thus allowing advances in new selection cycles. In general, the highest $\mathrm{CV}_{\mathrm{g}}$ values were observed in the third harvest $(\mathrm{H} 3)$, followed by the first $(\mathrm{H} 1)$, but the pulp weight, number of fruits and productivity stood out in the second (H2) harvest (Table 1).

Table 1. Genetic parameters of nine physical and chemical traits of fruits from 14 hybrids of sour passion fruit analyzed at $184(\mathrm{H} 1), 334$ ( $\mathrm{H} 2)$ and $441(\mathrm{H} 3)$ DAP.

\begin{tabular}{|c|c|c|c|c|c|c|c|c|c|c|c|}
\hline Parameters & & Harvest & FW & FL & FD & PT & PW & PuW & JY & NF & PR \\
\hline \multirow{3}{*}{$\mathrm{CV}_{\mathrm{g}}$} & & $\mathrm{H} 1$ & 13.40 & 7.98 & 3.96 & 10.87 & 16.47 & 13.86 & 8.14 & 13.10 & 17.07 \\
\hline & & $\mathrm{H} 2$ & 12.93 & 7.70 & 4.45 & 9.92 & 12.90 & 16.26 & 5.25 & 19.29 & 21.02 \\
\hline & & $\mathrm{H} 3$ & 16.08 & 9.42 & 5.67 & 4.78 & 20.84 & 13.60 & 12.80 & 18.93 & 12.94 \\
\hline \multirow{3}{*}{$\mathrm{CV}_{\mathrm{e}}$} & & $\mathrm{H} 1$ & 11.65 & 6.00 & 4.21 & 11.21 & 13.28 & 17.77 & 14.03 & 26.73 & 33.47 \\
\hline & & $\mathrm{H} 2$ & 15.96 & 6.36 & 5.78 & 15.75 & 18.43 & 23.57 & 15.91 & 24.11 & 26.61 \\
\hline & & $\mathrm{H} 3$ & 18.48 & 22.98 & 5.73 & 15.42 & 17.81 & 34.00 & 32.00 & 22.27 & 25.88 \\
\hline \multirow{3}{*}{$\mathrm{CV}_{\mathrm{g}} / \mathrm{CV}_{\mathrm{e}}$} & & $\mathrm{H} 1$ & 1.15 & 1.33 & 0.94 & 0.97 & 1.24 & 0.78 & 0.58 & 0.49 & 0.51 \\
\hline & & $\mathrm{H} 2$ & 0.81 & 1.21 & 0.77 & 0.63 & 0.70 & 0.69 & 0.33 & 0.80 & 0.79 \\
\hline & & $\mathrm{H} 3$ & 0.87 & 0.41 & 0.99 & 0.31 & 1.17 & 0.40 & 0.40 & 0.85 & 0.50 \\
\hline \multirow{3}{*}{$\sigma_{p}^{2}$} & & $\mathrm{H} 1$ & 884.73 & 0.69 & 0.19 & 1.23 & 372.04 & 119.12 & 21.95 & 51.12 & 2.31 \\
\hline & & $\mathrm{H} 2$ & 1683.43 & 0.82 & 0.31 & 1.10 & 406.32 & 342.70 & 27.86 & 113.61 & 5.44 \\
\hline & & $\mathrm{H} 3$ & 1511.15 & 4.25 & 0.38 & 1.18 & 638.81 & 215.99 & 69.29 & 1276.40 & 28.78 \\
\hline \multirow{9}{*}{$\%$ of $\sigma_{p}^{2}$} & \multirow{3}{*}{$\sigma_{g}^{2}$} & $\mathrm{H} 1$ & 57.05 & 63.77 & 47.37 & 48.78 & 60.75 & 37.84 & 25.19 & 19.41 & 20.78 \\
\hline & & $\mathrm{H} 2$ & 39.62 & 59.76 & 38.71 & 28.18 & 32.67 & 32.35 & 10.05 & 39.29 & 38.05 \\
\hline & & $\mathrm{H} 3$ & 42.95 & 14.59 & 50.00 & 8.47 & 57.86 & 13.55 & 14.04 & 41.76 & 20.29 \\
\hline & \multirow{3}{*}{$\sigma_{\mathrm{e}}^{2}$} & $\mathrm{H} 1$ & 42.95 & 36.23 & 52.63 & 52.03 & 39.25 & 62.16 & 74.81 & 80.58 & 78.79 \\
\hline & & $\mathrm{H} 2$ & 60.38 & 40.24 & 61.29 & 70.91 & 67.33 & 67.65 & 89.95 & 60.71 & 61.76 \\
\hline & & $\mathrm{H} 3$ & 57.05 & 85.65 & 50.00 & 91.53 & 42.14 & 86.45 & 85.96 & 58.24 & 79.74 \\
\hline & \multirow{3}{*}{$\mathrm{h}^{2}$} & $\mathrm{H} 1$ & 86.92 & 89.82 & 81.66 & 82.34 & 88.56 & 75.27 & 62.73 & 54.64 & 56.83 \\
\hline & & $\mathrm{H} 2$ & 76.64 & 87.98 & 74.91 & 66.74 & 70.81 & 70.51 & 35.81 & 76.39 & 75.50 \\
\hline & & $\mathrm{H} 3$ & 79.01 & 45.83 & 82.99 & 32.21 & 87.28 & 43.94 & 44.97 & 78.19 & 55.97 \\
\hline
\end{tabular}

FW: fruit weight; FL: fruit length;FD: fruit diameter; PT: peel thickness; PW: peel weight; PuW: pulp weight; JY:juice yield; NF: number of fruits; PR: productivity. CV : coefficient of

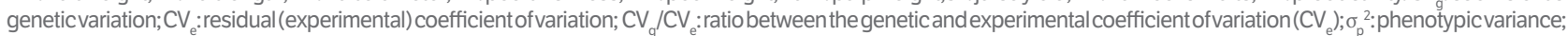
$\sigma_{\mathrm{g}}^{2}$ : genetic variance; $\sigma_{\mathrm{e}}^{2}$ : environmental variance; $h^{2}$ : heritability.

The $\mathrm{CV}_{\mathrm{e}}$ ranged from $34.00 \%$ ( $\mathrm{PuW}$ in $\mathrm{H} 3$ ) to $4.21 \%$ ( $\mathrm{FD}$ in $\mathrm{H} 1$ ), the majority being considered medium (10 to $20 \%$ ). Lower $\mathrm{CV}_{\mathrm{e}}$ values were observed in $\mathrm{H} 1$, except for $\mathrm{NF}$ and $\mathrm{PR}$, in which the values were higher (Table 1 ). The lack of fruiting uniformity in the $\mathrm{H} 1$ hybrids resulted in a higher $\mathrm{CV}_{\mathrm{e}}$, showing the variability in the precocity of production among the evaluated hybrids.

The parameter heritability ranged from 32.21 to $89.82 \%$ for PT (H3) and FL (H1), respectively. The highest values were observed in $\mathrm{H} 1$ for FW, FL, PT, PW, PuW and JY. For FD, NF and PR, the highest values were observed in the third and second evaluations, (Table 1). In general, $\mathrm{H} 1$ and $\mathrm{H} 2$ concentrated the highest heritabilities (62.73 to 89.82\%) of the characteristics. 


\section{Correlation}

There were 44 significant phenotypic correlations, with coefficients ranging from -0.74 to 0.96 . Of these, $20.4 \%$ were very strong correlations $(0.90<|\mathrm{r}|<1.0), 52.3 \%$ were strong correlations $(0.60<|\mathrm{r}| \leq 0.90)$ and $15.9 \%$ were medium $(0.30<|\mathrm{r}| \leq$ 0.60 ) (Table 2). Of the 44 significant phenotypic correlations, $9.09 \%$ had negative coefficients. On the other hand, genotypic correlations showed 58 significant correlations, with coefficients ranging from -0.85 to 1.00 , with $5.2 \%$ being classified as medium correlation, $41.4 \%$ strong correlation, $19 \%$ very strong and $10.3 \%$ of perfect correlation $(\mathrm{r}=1.00)$ (Carvalho et al. 2004).

For all harvests, there were positive and significant genotypic correlations between $\mathrm{FW} \times(\mathrm{FL}, \mathrm{FD}, \mathrm{PW}$ and $\mathrm{PuW})$; $\mathrm{FL} \times(\mathrm{FD}, \mathrm{PW}$ and $\mathrm{PuW})$ and $\mathrm{NF} \times \mathrm{PR}$. The PT only showed significance with the traits FW, FL, FD, PW and PuW (in the third harvest); with NF (in the second harvest) and with PR (in the second and third). In addition to PT, PR showed significance for positive correlations ranging from 0.56 to 1.00 with the third $(\mathrm{H} 3)$ and first $(\mathrm{H} 1)$ harvest, respectively of the traits FW, FL, FD and PW. For NF, the third harvest showed a negative and significant genetic correlation for FW $(-0.82)$, FL (-0.65), FD (-0.75), PW $(-0,85)$ and PuW $(-0.68)$, while the first and second harvests had few correlated characteristics, the exception being NF $\times$ JY $(-0.57)$ in the first harvest and NF $\times$ FL $(-0.73)$ and NF $\times$ PT $(-0.66)$ in the second harvest (Table 2).

Table 2. Estimation of phenotypic (upper diagonal) and genotypic (lower diagonal) correlations for nine traits of 14 hybrids of sour passion fruit analyzed at $184(\mathrm{H} 1), 334(\mathrm{H} 2)$ and $441(\mathrm{H} 3)$ DAP.

\begin{tabular}{|c|c|c|c|c|c|c|c|c|c|c|}
\hline & Harvest & FW & FL & FD & PT & PW & PuW & $J Y$ & NF & PR \\
\hline \multirow{3}{*}{ FW } & $\mathrm{H} 1$ & & $0.94^{* *}$ & $0.95^{\star *}$ & $0.10^{\text {ns }}$ & $0.91^{\star *}$ & $0.72^{* *}$ & $-0.19^{\text {ns }}$ & $0.02^{\mathrm{ns}}$ & $0.65^{*}$ \\
\hline & $\mathrm{H} 2$ & & $0.86^{\star *}$ & $0.90^{* *}$ & $0.12^{\mathrm{ns}}$ & $0.94^{* *}$ & $0.93^{* *}$ & $0.41^{\text {ns }}$ & $-0.33^{\text {ns }}$ & $0.36^{\mathrm{ns}}$ \\
\hline & $\mathrm{H} 3$ & & $0.62^{*}$ & $0.96^{* *}$ & $0.53^{\star}$ & $0.94^{* *}$ & $0.66^{*}$ & $-0.21^{\mathrm{ns}}$ & $-0.70^{* *}$ & $0.09^{\text {ns }}$ \\
\hline \multirow{3}{*}{$\mathrm{FL}$} & $\mathrm{H} 1$ & $0.98^{* *}$ & & $0.86^{* *}$ & $0.20^{\text {ns }}$ & $0.94^{* *}$ & $0.60^{\star}$ & $-0.30^{\text {ns }}$ & $0.10^{\text {ns }}$ & $0.64^{*}$ \\
\hline & $\mathrm{H} 2$ & $0.88^{* *}$ & & $0.68^{* *}$ & $0.25^{\mathrm{ns}}$ & $0.85^{\star *}$ & $0.74^{* *}$ & $0.18^{\text {ns }}$ & $-0.61^{*}$ & $-0.02^{\text {ns }}$ \\
\hline & $\mathrm{H} 3$ & $0.94^{* *}$ & & $0.53^{*}$ & $0.31^{\mathrm{ns}}$ & $0.69^{* *}$ & $0.19^{\text {ns }}$ & $-0.35^{\mathrm{ns}}$ & $-0.35^{n s}$ & $0.21^{\text {ns }}$ \\
\hline \multirow{3}{*}{ FD } & $\mathrm{H} 1$ & $0.96^{* *}$ & $0.90^{* *}$ & & $0.17^{\text {ns }}$ & $0.82^{* *}$ & $0.80^{* *}$ & $0.00^{\text {ns }}$ & $-0.01^{\text {ns }}$ & $0.59^{*}$ \\
\hline & $\mathrm{H} 2$ & $0.92^{* *}$ & $0.70^{* *}$ & & $0.00^{\text {ns }}$ & $0.86^{* *}$ & $0.89^{* *}$ & $0.44^{\text {ns }}$ & $-0.28^{\text {ns }}$ & $0.34^{\text {ns }}$ \\
\hline & $\mathrm{H} 3$ & $1.00^{* *}$ & $0.76^{* *}$ & & $0.51^{\text {ns }}$ & $0.94^{* *}$ & $0.54^{*}$ & $-0.34^{\mathrm{ns}}$ & $-0.64^{*}$ & $0.11^{\text {ns }}$ \\
\hline \multirow{3}{*}{ PT } & $\mathrm{H} 1$ & $0.14^{\mathrm{ns}}$ & $0.23^{\text {ns }}$ & $0.27^{\text {ns }}$ & & $0.40^{\text {ns }}$ & $-0.15^{\mathrm{ns}}$ & $-0.39^{\text {ns }}$ & $0.27^{\text {ns }}$ & $0.21^{\mathrm{ns}}$ \\
\hline & $\mathrm{H} 2$ & $0.06^{\text {ns }}$ & $0.31^{\text {ns }}$ & $-0.11^{\text {ns }}$ & & $0.18^{\text {ns }}$ & $-0.04^{\mathrm{ns}}$ & $-0.30^{\text {ns }}$ & $-0.44^{\text {ns }}$ & $-0.39^{n s}$ \\
\hline & $\mathrm{H} 3$ & $0.97^{* *}$ & $0.96^{* *}$ & $0.99^{* *}$ & & $0.64^{*}$ & $0.20^{\text {ns }}$ & $-0.23^{\text {ns }}$ & $-0.70^{* *}$ & $-0.43^{\text {ns }}$ \\
\hline \multirow{3}{*}{ PW } & $\mathrm{H} 1$ & $0.93^{* *}$ & $1.00^{* *}$ & $0.86^{*}$ & $0.46^{\text {ns }}$ & & $0.52^{\mathrm{ns}}$ & $-0.39^{\text {ns }}$ & $0.14^{\mathrm{ns}}$ & $0.67^{\star *}$ \\
\hline & $\mathrm{H} 2$ & $0.97^{\star \star}$ & $0.89^{* *}$ & $0.87^{* *}$ & $0.10^{\text {ns }}$ & & $0.82^{* *}$ & $0.20^{\text {ns }}$ & $-0.24^{\mathrm{ns}}$ & $0.39^{\text {ns }}$ \\
\hline & $\mathrm{H} 3$ & $0.96^{* *}$ & $1.00^{* *}$ & $0.96^{* *}$ & $1.00^{\star *}$ & & $0.43^{\text {ns }}$ & $-0.40^{\mathrm{ns}}$ & $-0.74^{* *}$ & $-0.06^{\mathrm{ns}}$ \\
\hline \multirow{3}{*}{ PuW } & $\mathrm{H} 1$ & $0.77^{* *}$ & $0.69^{* *}$ & $0.88^{* *}$ & $-0.06^{\mathrm{ns}}$ & $0.60^{*}$ & & $0.53^{*}$ & $-0.16^{\mathrm{ns}}$ & $0.37^{\mathrm{ns}}$ \\
\hline & $\mathrm{H} 2$ & $1.00^{\star *}$ & $0.76^{* *}$ & $1.00^{\star *}$ & $-0.10^{\text {ns }}$ & $0.88^{* *}$ & & $0.70^{\star *}$ & $-0.28^{\text {ns }}$ & $0.39^{\text {ns }}$ \\
\hline & $\mathrm{H} 3$ & $0.67^{* *}$ & $0.33^{\text {ns }}$ & $0.59^{*}$ & $0.56^{*}$ & $0.45^{\mathrm{ns}}$ & & $0.58^{*}$ & $-0.49^{n s}$ & $0.09^{n s}$ \\
\hline \multirow{3}{*}{$J Y$} & $\mathrm{H} 1$ & $-0.24^{\mathrm{ns}}$ & $-0.35^{\text {ns }}$ & $0.01^{\text {ns }}$ & $-0.38^{\text {ns }}$ & $-0.43^{\text {ns }}$ & $0.44^{\text {ns }}$ & & $-0.31^{\text {ns }}$ & $-0.31^{\text {ns }}$ \\
\hline & $\mathrm{H} 2$ & $0.66^{* *}$ & $0.16^{\text {ns }}$ & $0.84^{* *}$ & $-0.50^{\mathrm{ns}}$ & $0.31^{\text {ns }}$ & $0.76^{* *}$ & & $-0.06^{\mathrm{ns}}$ & $0.30^{\mathrm{ns}}$ \\
\hline & $\mathrm{H} 3$ & $-0.51^{\mathrm{ns}}$ & $-0.75^{* *}$ & $-0.67^{* *}$ & $-0.49^{n s}$ & $-0.68^{* *}$ & $0.27^{\text {ns }}$ & & $0.06^{\text {ns }}$ & $-0.05^{n s}$ \\
\hline \multirow{3}{*}{$\mathrm{NF}$} & $\mathrm{H} 1$ & $-0.02^{\mathrm{ns}}$ & $0.10^{\text {ns }}$ & $-0.09^{\text {ns }}$ & $0.42^{\text {ns }}$ & $0.21^{\mathrm{ns}}$ & $-0.32^{\text {ns }}$ & $-0.57^{\star}$ & & $0.76^{* *}$ \\
\hline & $\mathrm{H} 2$ & $-0.39^{\text {ns }}$ & $-0.73^{* *}$ & $-0.33^{\text {ns }}$ & $-0.66^{\star}$ & $-0.26^{\mathrm{ns}}$ & $-0.31^{\text {ns }}$ & $0.04^{\text {ns }}$ & & $0.75^{* *}$ \\
\hline & $\mathrm{H} 3$ & $-0.82^{* *}$ & $-0.65^{\star}$ & $-0.75^{* *}$ & $-1.00^{\text {ns }}$ & $-0.85^{\star *}$ & $-0.68^{\star *}$ & $0.21^{\text {ns }}$ & & $0.63^{*}$ \\
\hline \multirow{3}{*}{ PR } & $\mathrm{H} 1$ & $0.76^{\star \star}$ & $0.80^{* *}$ & $0.67^{* *}$ & $0.35^{\text {ns }}$ & $0.87^{* *}$ & $0.39^{\text {ns }}$ & $-0.54^{*}$ & $0.62^{*}$ & \\
\hline & $\mathrm{H} 2$ & $0.34^{\text {ns }}$ & $-0.1^{\mathrm{ns}}$ & $0.35^{\mathrm{ns}}$ & $-0.63^{\star}$ & $0.41^{\text {ns }}$ & $0.45^{\mathrm{ns}}$ & $0.67^{\star *}$ & $0.74^{* *}$ & \\
\hline & $\mathrm{H} 3$ & $-0.08^{\text {ns }}$ & $0.19^{\text {ns }}$ & $-0.01^{\text {ns }}$ & $-0.82^{* *}$ & $-0.23^{\text {ns }}$ & $-0.11^{\text {ns }}$ & $-0.14^{\text {ns }}$ & $0.63^{*}$ & \\
\hline
\end{tabular}

FW: fruit weight; FL: fruit length; FD: fruit diameter; PT: peel thickness; PW: peel weight; PuW: pulp weight; JY: juice yield; NF: number of fruits; PR: productivity. ${ }^{\star},{ }^{\star \star}$, ns significant at 1 and $5 \%$ and not significant by the T-test, respectively. 


\section{Repeatability}

For each evaluated characteristic, five measurements were carried out in four blocks. There was variation in the repeatability coefficient for all estimation methods, ranging from $\hat{r}=0.03$ for peel thickness in $\mathrm{H} 3$ to $\hat{r}=0.66$ for $\mathrm{FL}$, in the first harvest cycle $(\mathrm{H} 1)$. The magnitudes of the repeatability coefficients $(\hat{r})$ were identical between ANOVA and SACOR and also identical between PCCOV and PCCOR. However, based on the repeatability and determination coefficients $\left(\hat{r}\right.$ and $\mathrm{R}^{2}$ ), there was a slight increase in the estimate when using PCCOV and PCCOR (Table 3 ).

Table 3. Estimates of the repeatability coefficient $(\hat{r})$ and its determination coefficients $\left(\mathrm{R}^{2}\right)$ and number of measurements required considering $R^{2}$ values of 85,90 and $95 \%$ based on data from fruit traits analyzed at $184(\mathrm{H} 1), 334(\mathrm{H} 2)$ and $441(\mathrm{H} 3)$ DAP of 14 sour passion fruit hybrids.

\begin{tabular}{|c|c|c|c|c|c|c|c|c|c|c|c|}
\hline \multirow{3}{*}{ Character } & \multirow{3}{*}{ Harvest } & \multicolumn{5}{|c|}{ ANOVA/SACOR } & \multicolumn{5}{|c|}{ PCCOV/PCCOR } \\
\hline & & \multirow[b]{2}{*}{$\hat{r}$} & \multirow[b]{2}{*}{$\mathbf{R}^{2+}$} & \multicolumn{3}{|c|}{$\mathbf{N}^{\circ}$ of measurement $\mathbf{R}^{2}(\%)$} & \multirow[b]{2}{*}{$\hat{r}$} & \multirow[b]{2}{*}{$\mathbf{R}^{2+}$} & \multicolumn{3}{|c|}{$N^{\circ}$ of measurement $R^{2}(\%)$} \\
\hline & & & & 85 & 90 & 95 & & & 85 & 90 & 95 \\
\hline \multirow{3}{*}{ FW } & $\mathrm{H} 1$ & 0.60 & 88.50 & 3.68 & 5.84 & 12.34 & 0.61 & 88.91 & 3.53 & 5.60 & 11.84 \\
\hline & $\mathrm{H} 2$ & 0.38 & 76.03 & 8.93 & 14.18 & 29.95 & 0.42 & 78.32 & 7.84 & 12.46 & 26.30 \\
\hline & $\mathrm{H} 3$ & 0.42 & 78.58 & 7.72 & 12.26 & 25.88 & 0.47 & 81.55 & 6.40 & 10.18 & 23.58 \\
\hline \multirow{3}{*}{$\mathrm{FL}$} & $\mathrm{H} 1$ & 0.66 & 90.63 & 2.93 & 4.65 & 9.82 & 0.66 & 90.79 & 2.87 & 4.56 & 9.63 \\
\hline & $\mathrm{H} 2$ & 0.57 & 86.87 & 4.28 & 6.79 & 14.35 & 0.57 & 87.01 & 4.23 & 6.72 & 14.18 \\
\hline & $\mathrm{H} 3$ & 0.58 & 87.75 & 3.95 & 6.28 & 13.26 & 0.59 & 87.95 & 3.88 & 6.16 & 13.01 \\
\hline \multirow{3}{*}{ FD } & $\mathrm{H} 1$ & 0.48 & 82.06 & 6.19 & 9.87 & 20.76 & 0.51 & 83.64 & 5.54 & 8.80 & 18.58 \\
\hline & $\mathrm{H} 2$ & 0.35 & 72.64 & 10.67 & 16.95 & 35.78 & 0.38 & 75.47 & 9.21 & 14.63 & 30.88 \\
\hline & $\mathrm{H} 3$ & 0.29 & 67.74 & 10.02 & 15.91 & 33.58 & 0.33 & 70.81 & 8.44 & 13.41 & 28.31 \\
\hline \multirow{3}{*}{ PT } & $\mathrm{H} 1$ & 0.56 & 86.58 & 4.39 & 6.97 & 14.72 & 0.57 & 87.11 & 4.19 & 6.66 & 14.06 \\
\hline & $\mathrm{H} 2$ & 0.28 & 66.33 & 14.38 & 22.84 & 48.22 & 0.31 & 69.66 & 12.33 & 19.59 & 41.36 \\
\hline & $\mathrm{H} 3$ & 0.03 & 12.64 & 19.58 & 31.09 & 65.64 & 0.29 & 67.30 & 13.76 & 21.86 & 46.12 \\
\hline \multirow{3}{*}{ PW } & $\mathrm{H} 1$ & 0.58 & 87.26 & 4.14 & 6.57 & 13.87 & 0.61 & 88.62 & 3.40 & 5.87 & 12.2 \\
\hline & $\mathrm{H} 2$ & 0.29 & 67.18 & 13.84 & 21.97 & 46.39 & 0.37 & 74.93 & 9.48 & 15.06 & 31.78 \\
\hline & $\mathrm{H} 3$ & 0.49 & 83.00 & 5.80 & 9.21 & 19.46 & 0.50 & 83.41 & 5.63 & 8.95 & 18.89 \\
\hline \multirow{3}{*}{ PuW } & $\mathrm{H} 1$ & 0.42 & 78.52 & 7.74 & 12.31 & 25.98 & 0.46 & 80.98 & 6.66 & 10.57 & 22.32 \\
\hline & $\mathrm{H} 2$ & 0.32 & 69.83 & 12.24 & 19.44 & 41.03 & 0.35 & 73.40 & 10.26 & 16.3 & 34.42 \\
\hline & $\mathrm{H} 3$ & 0.16 & 49.10 & 22.73 & 36.09 & 76.21 & 0.23 & 60.16 & 21.50 & 34.13 & 72.05 \\
\hline \multirow{3}{*}{$J Y$} & $\mathrm{H} 1$ & 0.19 & 55.49 & 22.73 & 36.09 & 76.21 & 0.25 & 62.80 & 16.78 & 26.65 & 56.27 \\
\hline & $\mathrm{H} 2$ & 0.17 & 50.77 & 27.47 & 43.63 & 92.12 & 0.24 & 61.26 & 17.91 & 28.45 & 60.07 \\
\hline & $\mathrm{H} 3$ & 0.20 & 55.49 & 22.73 & 36.09 & 76.21 & 0.21 & 56.86 & 21.48 & 34.13 & 72.05 \\
\hline \multirow{3}{*}{ NF } & $\mathrm{H} 1$ & 0.18 & 53.02 & 25.10 & 39.86 & 84.16 & 0.25 & 63.23 & 16.48 & 26.17 & 55.25 \\
\hline & $\mathrm{H} 2$ & 0.37 & 74.64 & 9.62 & 15.28 & 32.27 & 0.40 & 77.00 & 8.46 & 13.44 & 28.37 \\
\hline & $\mathrm{H} 3$ & 0.36 & 73.66 & 10.13 & 16.09 & 33.97 & 0.44 & 79.74 & 7.20 & 11.43 & 24.14 \\
\hline \multirow{3}{*}{ PR } & $\mathrm{H} 1$ & 0.30 & 68.20 & 13.21 & 20.98 & 44.29 & 0.33 & 71.37 & 11.36 & 18.05 & 38.11 \\
\hline & $\mathrm{H} 2$ & 0.34 & 71.93 & 11.05 & 17.56 & 37.06 & 0.37 & 74.72 & 9.58 & 15.22 & 32.14 \\
\hline & & 0.19 & 53.75 & 24.38 & 38.73 & 81.76 & 0.24 & 61.31 & 17.88 & 28.39 & 59.94 \\
\hline
\end{tabular}

$\hat{r}$ : repeatability coefficient; $\mathrm{R}^{2}$ : genotypic determination coefficient; ANOVA: analysis of variance; PCCOV: principal components obtained from the phenotypic variance and covariance matrix; PCCOR: principal components obtained from the correlation matrix; SACOR: structural analysis based on the theoretical eigenvalue of the correlation matrix or mean correlation; FW: fruit weight; FL: fruit length; FD: fruit diameter; PT: peel thickness; PW: peel weight; PuW: pulp weight; JY: juice yield; NF: number of fruits; PR: productivity.

Among the evaluated harvests, mean repeatability $(\hat{r})$ and determination $\left(\mathrm{R}^{2}\right)$ coefficients per harvest were $\hat{r}=0.46$ and $\mathrm{R}^{2}=78.21 \%$ for $\mathrm{H} 1 ; \hat{r}=0.36$ and $\mathrm{R}^{2}=72.67$ for $\mathrm{H} 2$, and $\hat{r}=0.33$ and $\mathrm{R}^{2}=67.27 \%$ for $\mathrm{H} 3$, indicating greater accuracy 
of the information obtained in the first harvest due to less environmental variation (Table 3). On the other hand, traits such as JY, NF and PR in general showed lower results for the coefficients of repeatability and determination. For these variables, the effect of the harvest was not as great as observed for the other traits (Table 3), which may be related to the greater environmental variance of the harvests for these traits (Table 1).

Based on the PCCOV and PCCOR estimates, the number of measurements necessary to predict the real value of the physical characteristics of passion fruit and productivity when analyzed with $90 \%$ accuracy was 13 fruits in the first harvest, 16 in the second and 18 in the third harvest (Table 3). The smallest numbers of fruits $(<10.0)$ necessary to predict the real value with $90 \%$ precision were observed for the traits FW, FL, FD, PT and PW when evaluated in the first harvest based on in the PCCOV and PCCOR methods (Table 3).

A high number of samples with $90 \%$ accuracy according to the PCCOV and PCCOR methods was necessary in the first harvest to predict important characteristics, such as JY $(n=26)$ and PR $(n=18)$ (Table 3). This effect was also associated with high environmental variance and low heritability of these characteristics, especially in the first harvest (Table 1). Despite this, pulp weight and productivity showed high correlation with fruit weight in the first harvest, which is a characteristic that is easy to measure and thus can be used in evaluations, especially when many genotypes are evaluated (Table 2).

\section{DISCUSSION}

The evaluation of genotypes in breeding programs is time-consuming and costly, so reduction of the evaluation period without compromising accuracy of the information is extremely relevant (Neves et al. 2010; Cavalcante et al. 2017, 2018; Mendes and Ramalho 2018). Passion fruit production is low in the first year, tends to increase in the second year and decreases again in the third year (Pimentel et al. 2008). The study of parameters such as correlations and repeatability in different harvests can contribute to the identification of the production phase that provides greater gains in selection, in addition to allowing better inference of the characterization information based on the data of fruit traits over multiple harvests.

In this study, the measurements were performed $184(\mathrm{H} 1), 334(\mathrm{H} 2)$ and $441(\mathrm{H} 3)$ days after planting (DAP). The genetic parameters varied according to the harvests $(\mathrm{H} 1, \mathrm{H} 2$ and $\mathrm{H} 3)$ and $\mathrm{CV}_{\mathrm{e}}$, phenotypic $\left(\sigma_{\mathrm{p}}{ }^{2}\right)$ and environmental variance $\left(\sigma_{\mathrm{e}}{ }^{2}\right)$ values increased with harvests, while for genetic variance $\left(\sigma_{\mathrm{g}}^{2}\right), \mathrm{CV}_{\mathrm{g}} / \mathrm{CV}_{\mathrm{e}}$ ratio and heritability $\left(\mathrm{h}^{2}\right)$ the values decreased from harvest $\mathrm{H} 1$ to $\mathrm{H} 3$ and for $\mathrm{CV}_{\mathrm{g}}$ there was little variation $(\mathrm{H} 1$ to $\mathrm{H} 3)$ for most characters.

The changes in the estimated values for the evaluated parameters reflect the most pronounced influence of environmental effects on the characters of $\mathrm{H} 2$ to $\mathrm{H} 3$, consequently contributing to the different values observed in the parameters in $\mathrm{H} 1$ to H3. A strong reduction in heritability in the third harvest was observed for the parameters FL, PT, PuW and PR (Table 1) due to the greater environmental variation $\left(\sigma_{e}^{2}\right)$. However, the values of $\mathrm{h}^{2}$ and $\mathrm{CV}_{\mathrm{g}}$ showed the existence of genetic variability and a favorable condition for selection, especially for important characters such as observed for $\mathrm{H} 1$ regarding FW, FL and PW, showing lower $\mathrm{CV}_{\mathrm{e}}$ and high values at median $\mathrm{CV}_{\mathrm{g}}$ and heritability values above $80 \%$. For number of fruits and productivity, the second and third harvests were more suitable for selecting superior individuals, respectively.

The values obtained were within the reported range of 4.13 to $28.38 \%$ for $\mathrm{CV}_{\mathrm{e}}$ (Silva et al. 2012). According to Oliveira et al. (2008), values below $20.48 \%$ are considered to denote good experimental accuracy for sour passion fruit. The studied population of passion fruit hybrids has already undergone a selective process, but still showed high $\mathrm{CV}_{\mathrm{g}}$ in the first harvest compared to similar studies (Moraes et al. 2005; Oliveira et al. 2008; Silva et al. 2012). This reflects the potential of these hybrids to follow the stages of genetic improvement for the development of cultivars.

The values observed for the coefficients of genotypic correlation exceeded those of phenotypic correlation (Tables 1 and 2), reinforcing the presence of genetic variability in the studied population (Table 1). This result is advantageous to the selection process, since the genetic effects overlap with the environmental effects in the manifestation of phenotype (Silva et al. 2012). For the variables FW, FL, FD, PW and PuW, the pairwise correlations were high and positive in the three evaluation harvests, indicating that the correlations between the traits were maintained between the different periods. 
The results obtained suggest that an increase in fruit weight would imply gains in length, diameter, $\mathrm{PW}$ and PuW at any time of selection, but the negative impact on the number of fruits is more evident in the third harvest.

High positive genetic correlations were observed between FL and FD, as well as between FD and PW. This last correlation is interesting, since PW is associated with lower JY, which is undesirable $(r=-0.68)$, so this correlation allows the selection for lower PW based on the measurement of FL in the field. This type of correlation has also been reported in other studies (Oliveira et al. 2008; Alves et al. 2012). However, in general, the variables PT, PR and NF only showed a significant positive correlation [NF or PT $\mathrm{x}$ (FW, FL, FD, PW and PuW)] in H3 and negative correlation [PR x (FW, FL, FD, PW and PuW)] in H1.

Therefore, depending on the harvest, there may be no correlation between the traits, which can interfere with the gains when the selection of one variable is used for gain or loss in another (indirect selection). In addition, the presence of negative or positive correlations between certain traits of agronomic interest implies the use of selection methods that take them into account when choosing superior genotypes (Greco et al. 2015). Changes in values and type of correlations need to be evaluated experimentally to verify whether this association is transient, i.e., whether selection based on the first cycle will promote a different response in relation to another in the following cycles.

The repeatability analysis was performed within each harvest ( $\mathrm{H} 1$ to $\mathrm{H} 3)$ in order to verify the consistency of the fruit characters measured within the plots. Repeatability studies of $P$. edulis are scarce (Santos et al. 2010; Neves et al. 2010), especially in association with other analyses for phase selection. In this study, it was possible to select traits based on the coefficients of repeatability $(\hat{r})$ and determination $\left(\mathrm{R}^{2}\right)$ and more reliable estimates were obtained for the principal components based on PCCOV, and the principal components based on the PCCOR in the H1 in relation to $\mathrm{H} 2$ and $\mathrm{H} 3$. The values of $\hat{r}$ were medium to high (Resende 2002) and a value above 0.5 for the repeatability coefficient is considered reasonable for data reliability (Shimoya et al. 2002). Probably the low performance presented by the method based on ANOVA is also associated with the environmental variations that affected the characters evaluated. This observation has also been reported in other studies involving ANOVA (Neves et al., 2010; Santos et al. 2010; Vasconcelos et al. 2000).

Besides that, the low coefficients of repeatability in the second and third harvests may be related to environmental variation, which leads to less stability of the characteristic, causing a need to obtain a greater quantity of measurements to achieve accuracy of the results (Lessa et al. 2014). Due to the greater environmental variation observed in the last two harvests, the repeatability coefficient was lower regardless of the method used and consequently the number of samples necessary to obtain $90 \%$ accuracy was greater in the second and third harvests.

The minimum number of necessary measurements observed by Santos et al. (2010) for the characters pulp, peel and fruit weight were 18,10 and 12 , respectively. These values were higher than those observed in this study (10, 5 and 5 , respectively) in the first harvest to predict the real value of the genotypes with $90 \%$ accuracy by PCCOV. Neves et al. (2010), using the same method, found that 15 and 16 measurements per genotype for fruit weight and pulp weight would be necessary to reach a determination coefficient of $90 \%$. This result may be associated with the experimental conditions and the period of sampling and evaluation of the physical characteristics of the fruits, since an average increase of $32 \%$ was observed in the number of fruits necessary to obtain $90 \%$ accuracy in the third evaluation compared to the first by the PCCOV method (Table 3).

The genetic parameters differed significantly depending on the harvest, with high values for the first harvest, particularly genetic variance and heritability of the physical characteristics of fruits. This shows that the selection criteria, considering the three evaluation periods (harvests at 184 [H1], 334 [H2] and 441 [H3] DAP), can change, so the selection made at different times can result in different responses to selection.

Evaluations performed in the first harvest reduced the time spent in the breeding program to obtain superior individuals, meaning greater efficiency in the process of selection and validation of genetically superior genotypes (Santos et al. 2010). However, Pimentel et al. (2008) observed that the second year of production (450 to 660 DAP) expressed greater correlations than the first cycle (150 to $330 \mathrm{DAP}$ ), due to the unevenness in the initial development of plants under field conditions, which can interfere in productivity in the first harvest. However, in general, greater heritability, genotypic variance, genotypic correlation and repeatability $(\hat{r})$ and determination $\left(\mathrm{R}^{2}\right)$ coefficients were observed and less variance and number of samples 
required for $90 \%$ accuracy in $\mathrm{H} 1$ (184 DAP) under the evaluation conditions of this study. This result is similar to that reported by Cavalcante et al. (2017), who obtained the highest average heritability $\left(h^{2}\right)$ for fruit production in the first year of cultivation, while fruit number and fruit weight were high both in the first year and the full cycle.

The first harvest at 184 DAP under the conditions of this study can be used for the selection of superior individuals for gains in most of the characteristics related to the fruit by presenting low environmental variations and high heritabilities, accelerating the selection process. The correlations between the traits changed according to the evaluation cycle, however, the correlations between the traits FW, FL, FD, PW and PuW were more stable in the different harvests. Through the repeatability analysis based on the principal components of covariance and correlation, it was possible to estimate a sample of 13 fruits per hybrid for prediction, with accuracy of $90 \%$ for the physical traits of yellow passion fruit.

\section{CONCLUSION}

The evaluated genetic parameters showed different behavior depending on the time of evaluation of the characters of the fruits and production. The environmental component was more pronounced in the phenotypic expression of most of the characters in the harvests $334(\mathrm{H} 2)$ and 441 (H3) DAP, thus contributing to the lowest estimate of genetic components in the evaluated population. With exception of NF (H3) and PR (H2), the evaluations carried out at $184 \mathrm{DAP}(\mathrm{H} 1)$ showed the highest values of the genetic parameters. Due to the wide variability in the passion fruit sour hybrids (P. edulis), for better accuracy in the measurements of the evaluated characters, it is necessary to evaluate at least 13 fruits to predict the real value of the genotypes in the first harvest with $90 \%$ accuracy..

\section{AUTHORS' CONTRIBUTION}

Conceptualization: Jesus O. N., Lima L. K. S., Souza, P. U. and Girardi E. A.; Methodology: Lima L. K. S. and Jesus, O. N. Investigation: Souza, P. U. Writing - Original Draft: Jesus, O. N., Lima, L. K. S., Souza P. U. and Girardi E. A. Writing - Review and Editing: Jesus O. N. and Lima L. K. S.; Funding Acquisition: Jesus O. N; Resources: Jesus O. N; Supervision: Girardi E. A.

\section{DATA AVAILABILITY STATEMENT}

Data sharing is not applicable.

\section{FUNDING}

Empresa Brasileira de Pesquisa Agropecuária

http://doi.org/10.13039/501100003046

Grant No. 22.16.04.007.00.00; 24.17.00.015.00.00

Conselho Nacional de Desenvolvimento Científico e Tecnológico

http://doi.org/10.13039/501100003593

Grant No. 421033/2018-5; 312774/2018-4; Grant No. PDJ - 152109/2019-6

Coordenação de Aperfeiçoamento de Pessoal de Nível Superior

http://doi.org/10.13039/501100002322 


\section{ACKNOWLEDGMENTS}

The Embrapa Embrapa Mandioca e Fruticultura research unit provided the plant material along with technical support. The companies Bioenergia Orgânicos provided field support and AGROCINCO donated seed material of hybrids BRS-GA1 and BRS-SC1. The Coordenação de Aperfeiçoamento de Pessoal de Nível Superior for granting the master's scholarship to the third author. To Sindara Ribeiro Sampaio and Alirio Cruz Neto for their support in fruit evaluations.

\section{REFERENCES}

[EMBRAPA] Empresa Brasileira de Pesquisa Agropecuária. (1999). Sistema Brasileiro de Classificação de Solos. Brasília: Embrapa.

[EMBRAPA] Empresa Brasileira de Pesquisa Agropecuária. (2018). Sistema Orgânico de Produção do Maracujazeiro para a Região da Chapada Diamantina, Bahia. Embrapa Mandioca e Fruticultura, Sistemas de Produção, 48. [Accessed Aug. 20, 2020]. Available at: https://www.spo.cnptia.embrapa.br/

Abeywardena, V. (1972). An application of principal components analysis in genetics. Journal of Genetic, 61, 27-51.

Alves, R. R., Salomão, L. C. C., Siqueira, D. L., Cecon, P. R. and Silva, D. F. P. (2012). Relações entre características físicas e químicas de frutos de maracujazeiro-doce cultivado em Viçosa-MG. Revista Brasileira de Fruticultura, 34,619-623. https://doi.org/10.1590/S0100-29452012000200038

Bergo, C. L., Miqueloni, D. P., Pedrozo, C. Â. and Resende, M. D. V. (2019). Genetic parameters to production characters of palm heart in half-sibs progenies of palm peach. Ciência Rural, 49, e20180638. https://doi.org/10.1590/0103-8478cr20180638

Bruna, E. D., Moreto, A. L. and Dalbó, M. A. (2012). Uso do coeficiente de repetibilidade na seleção de clones de pessegueiro para o litoral sul de Santa Catarina. Revista Brasileira de Fruticultura, 34, 206-215. https://doi.org/10.1590/S0100-29452012000100028

Carvalho, F. I. F., Lorencetti, C. and Benin, G. (2004). Estimativas e implicações da correlação no melhoramento vegetal. Pelotas: UFPel.

Cavalcante, N. R., Krause, W., Viana, A. P., Silva, C. A., Porto, K. K. X. and Martinez, R. A. S. (2017). Anticipated selection for intrapopulation breeding of passion fruit. Acta Scientiarum Agronomy, 39, 143-148. https://doi.org/10.4025/actasciagron.v39i2.31022

Cavalcante, N. R., Viana, A. P., Santos, P. R., Preisigke, S. C., Ribeiro, R. M. and Tofanelli, E. J. (2018). Associations among production and physicochemical quality fruit traits in Passion fruit populations subjected to three cycles of intrapopulation recurrent selection. Revista Brasileira de Fruticultura, 40, e013. https://doi.org/10.1590/0100-29452018013

Cruz, C. D. (2013). Programa Genes: Aplicativo Computacional em Genética e Estatística. Viçosa: UFV. [Accessed Ago. 20, 2020]. Available at: http://arquivo.ufv.br/dbg/genes/genes_Br.htm

Cruz, C. D., Carneiro, P. C. S. and Regazzi, A. J. (2004). Modelos Biométricos Aplicados ao Melhoramento Genético. Viçosa: UFV.

Ferreira, A., Barbosa, M. H. P., Cruz, C. D., Hoffmann, H. P., Vieira, M. A. S., Bassinello, A. I. and Silva, M. F. D. (2005). Repetibilidade e número de colheitas para seleção de clones de cana-de-açúcar. Pesquisa Agropecuária Brasileira, 40, 761-767. https://doi.org/10.1590/ S0100-204X2005000800005

Greco, S. M. L., Peixoto, J. R. and Ferreira, L. M. (2015). Avaliação física, físico-química e estimativas de parâmetros genéticos de 32 genótipos de maracujazeiro-azedo cultivados no Distrito Federal. Bioscience Journal, 30, 360-370.

Jesus, O. N., Oliveira, E. J., Faleiro, F. G., Soares, T. L. and Girardi, E. A. (2017). Illustrated morpho-agronomic descriptors for Passiflora spp. Brasília: Embrapa. [Accessed Aug. 20, 2020]. Available at: https://bit.ly/3oR0SYp

Lessa, L. S., Ledo, C. A. S., Amorim, E. P. and Silva, S. O. (2014). Estimativas de repetibilidade de híbridos diploides (AA) de bananeira. Pesquisa Agropecuária Brasileira, 49, 109-117. https://doi.org/10.1590/S0100-204X2014000200005 
Lima, L. K. S., Santos, I. S., Goncalves, Z. S., Soares, T. L., Jesus, O. N. and Girardi, E. A. (2018). Grafting height does not affect Fusarium wilt control or horticultural performance of Passiflora gibertii N.E.Br. rootstock. Anais da Academia Brasileira de Ciências, 90, 35253539. https://doi.org/10.1590/0001-3765201820180072

Malek, M. A., Rafii, M. Y., Afroz, S. S., Nath, U. K. and Mondal, M. A. (2014). Morphological characterization and assessment of genetic variability, character association, and divergence in soybean mutants. The Scientific World Journal, 2014, 968796. https://doi.org/10.1155/2014/968796

Mansour, R., Nordheim, E. V. and Ruledge, J. J. (1981). Estimators of repeatability. Theorical Applied Genetics, 60, 151-156. https://doi. org/10.1007/BF00264520

Mendes, M. H. S. and Ramalho, M. A. P. (2018). Repeatability of some phenotypic stability parameters-a resampling approach. Crop Breeding and Applied Biotechnology, 18, 139-147. https://doi.org/10.1590/1984-70332018v18n2a20

Moraes, M. C., Geraldi, I. O., Matta, F. P. and Vieira, M. L. C. (2005). Genetic and Phenotypic Parameter Estimates for Yield and Fruit Quality Traits from a Single Wide Cross in Yellow Passion Fruit. Hort Science, 40, 1978-1981. https://doi.org/10.21273/HORTSCl.40.7.1978

Neves, L. G., Bruckner, C. H., Cruz, C. D. and Barelli, M. A. A. (2010). Avaliação da repetibilidade no melhoramento de famílias de maracujazeiro. Revista Ceres, 57, 480-485. https://doi.org/10.1590/S0034-737X2010000400007

Neves, C. G., Jesus, O. N., Ledo, C. A. S. and Oliveira, E. J. (2013). Avaliação Agronômica de parentais e Híbridos de mudas de maracujazeiroamarelo. Revista Brasileira de Fruticultura, 35, 191-198. https://doi.org/10.1590/S0100-29452013000100022

Oliveira, E. J., Santos, V. S., Lima, D. S., Machado, M. D., Lucena, R. S., Motta, T. B. N. and Castellen, M. S. (2008). Seleção em progênies de maracujazeiro-amarelo com base em índices multivariados. Pesquisa Agropecuária Brasileira, 43, 1543-1549. https://doi.org/10.1590/ S0100-204X2008001100013

Oliveira, E. J., Santos, V. S., Lima, D. S., Machado, M. D., Lucena, R. S. and Motta, T. B. N. (2011). Estimativas de correlações genotípicas e fenotípicas em germoplasma de maracujazeiro. Bragantia, 70, 255-261. https://doi.org/10.1590/S0006-87052011000200002

Oliveira, E. J., Soares, T. L., Barbosa, C. J., Santos-Filho, H. P. and Jesus, O. N. (2013). Severidade de doenças em maracujazeiro para identificação de fontes de resistência em condições de campo. Revista Brasileira de Fruticultura, 35, 485-492. https://doi.org/10.1590/S0100-29452013000200018

Pereira, P. P. A., Lima, L. K. S., Soares, T. L., Laranjeira, F. F., Jesus, O. N. and Girardi, E. A. (2019). Initial vegetative growth and survival analysis for the assessment of Fusarium wilt resistance in Passiflora spp. Crop Protection, 121, 195-203. https://doi.org/10.1016/j.cropro.2019.03.018

Pimentel, L. D., Stenzel, N. M. C., Cruz, C. D. and Bruckner, C. H. (2008). Seleção precoce de maracujazeiro pelo uso de correlação entre dados de produção mensal e anual. Pesquisa Agropecuária Brasileira, 43, 1303-1309. https://doi.org/10.1590/S0100-204X2008001000007

Resende, M. D. V. (2002). Genética biométrica e estatística no melhoramento de plantas perenes. Brasília: Embrapa.

Santos, C. M., Bruckner, C. H., Cruz, C. D., Siqueira, D. D., Pimentel, L. D. and Rosado, L. D. S. (2010). Repetibilidade em características do fruto do maracujazeiro. Revista Ceres, 57, 343-350. https://doi.org/10.1590/S0034-737X2010000300009

Santos, V. O., Viana, A. P, Preisigke, S. C. and Santos, E. A. (2019). Backcrosses in a segregating population of Passiflora mediated by morphoagronomic and resistance traits. Bragantia, 78, 542-552. https://doi.org/10.1590/1678-4499.20180470

Shimoya, A., Pereira, A. V., Ferreira, R. P., Cruz, C. D. and Carneiro, P. C. S. (2002). Repetibilidade de Características Forrageiras do Capim Elefante. Scientia Agricola, 59, 227-234. https://doi.org/10.1590/S0103-90162002000200004

Silva, M. G. M., Viana, A. P., Amaral Júnior, A. T., Gonçalves, L. S. A. and Reis, R. V. (2012). Biometria aplicada ao melhoramento intrapopulacional do maracujazeiro amarelo. Revista Ciência Agronômica, 43, 493-499. https://doi.org/10.1590/S1806-66902012000300011

Vasconcelos, C. J. J., Paiva, J. R., Levi, M. B., Crisostomo, J. B. and Correa, M. P. F. (2000). Repetibilidade de Caracteres de Produção e Porte da Planta em Clones de Cajueiro-Anão Precoce. Pesquisa Agropecuária Brasileira, 35, 773-777. https://doi.org/10.1590/ S0100-204X2000000400014 